University of Nebraska - Lincoln

DigitalCommons@University of Nebraska - Lincoln

$11-9-1992$

\title{
Simon Sulzer and the Consequences of the 1563 Strasbourg Consensus in Switzerland
}

Amy Nelson Burnett

University of Nebraska - Lincoln, aburnett1@unl.edu

Follow this and additional works at: https://digitalcommons.unl.edu/historyfacpub

Part of the History Commons

Burnett, Amy Nelson, "Simon Sulzer and the Consequences of the 1563 Strasbourg Consensus in Switzerland" (1992). Faculty Publications, Department of History. 2.

https://digitalcommons.unl.edu/historyfacpub/2

This Article is brought to you for free and open access by the History, Department of at DigitalCommons@University of Nebraska - Lincoln. It has been accepted for inclusion in Faculty Publications, Department of History by an authorized administrator of DigitalCommons@University of Nebraska - Lincoln. 
Originally published in Archive for Reformation History 83 (1992), pp. 154-179.

The Archive is published under the auspices of Verein für Reformationsgeschichte and the Society for Reformation Research. http://w3fp.arizona.edu/archive/

Copyright (C) 1992 Amy Nelson Burnett. Used by permission of the author. 


\title{
Simon Sulzer and the Consequences of the 1563 Strasbourg Consensus in Switzerland ${ }^{1}$
}

\author{
By Amy Nelson Bumett
}

From 1561 to 1563 the Strasbourg church was wracked by a bitter controversy between Johann Marbach, leader of the city's clergy, and Girolamo Zanchi, professor at the Strasbourg Academy. The controversy was finally resolved in March 1563, when the two parties signed a consensus on the disputed issues of predestination, the perseverance of the saints, and the Lord's Supper. ${ }^{2}$ Modern historians of doctrine generally discuss the Strasbourg controversy and the 1563 Consensus in the context of the struggle of later sixteenth-century Lutheranism to define orthodoxy, and they stress that the disagreement focused not on the sacrament of the altar but rather on what later became one of the hallmarks of the Reformed faith, the doctrine of predestination. ${ }^{3}$ Less well-known is the fact that the Strasbourg conflict had important repercussions within Switzerland, precisely because of the Consensus' statement on the Lord's Supper. The agreement signed in

1. Research for this article was supported by a grant from the Research Council of the University of Nebraska-Lincoln. I would like to thank the editors of the Bullinger correspondence in Zurich for their generous assistance. - Abbreviations: Beza Cor.: Correspondance de Théodore de Bèze (Geneva, 1960-). - CR. Calv. Op.: Corpus Reformatorum. Ioannis Calvini Opera quae Supersunt omnia (Braunschweig, 1863-1900). - AST: Strasbourg: Archives Municipales, Archives du Chapitre de Saint-Thomas. - BStA: Basel: Staatsarchiv. - ZStA: Zurich: Staatsarchiv. - ZZB. Ms S: Zurich: Zentralbibliothek, Simlersche Sammlung (also available on microform at the Center for Reformation Research in St. Louis).

2. The most detailed descriptions of the controversy are still the two older studies: Walter Sohm: Die Schule Johann Sturms und die Kirche Straßburgs in ihrem gegenseitigen Verhältnis 1530-1581 (Munich, 1912), 195-236; Charles Schmidt: "Girolamo Zanchi," Theologische Studien und Kritiken 32 (1859): 625-708 (especially 639-668).

3. See for example the two discussions by Bernhard Lohse and Wilhelm Neuser, 134-138 and 303-306 respectively, in: Handbuch der Dogmen-und Theologiegeschichte, 2. Die Lehrentwicklung im Rahmen der Konfessionalität, ed. by Carl Andresen (Göttingen, 1980), and Jürgen Moltmann's more detailed description of the controversy: Prädestination und Perseveranz. Geschichte und Bedeutung der reformierten Lehre "de perseverantia sanctorum" (Neukirchen, 1961), 75-106. James M. Kittelson emphasizes the institutional and jurisdictional issues which also fueled the controversy: "Marbach vs. Zanchi: The Resolution of Controversy in Late Reformation Strasbourg," Sixteenth Century Journal 8 (1977): 31-44. 
1563 may have ended the controversy in Strasbourg, but it threatened the unity of the four evangelical cities of German-speaking Switzerland, because one of its signatories was Simon Sulzer, antistes of the Basel church and rector of the city's university. ${ }^{4}$ Heinrich Bullinger and the leaders of the other Swiss churches attempted to use Sulzer's signature of the Consensus to remove Sulzer from his influential position in Basel because they regarded him as a dangerous theological enemy. Their failure set the stage for Basel's gradual alienation from the other Reformed churches and cities in Switzerland over the next two decades.

Sulzer was no stranger to Strasbourg. He had studied there briefly under Martin Bucer and Wolfgang Capito in the early 1530s. He also studied at Basel until he was called in 1538 to serve as preacher and professor of his home church in Bern. There he defended Bucer's attempts at conciliation with the Lutherans as embodied in the Wittenberg Concord, becoming head of what the Zwinglians regarded as a Lutheran faction in the Bern church. The Bern city council endured a decade of conflict between the Zwinglian and Lutheran parties before it finally decided in favor of the Zwinglians and relieved Sulzer of his position in 1548. Because his wife was from Basel, Sulzer moved his family there and soon found employment in the university and the church. He served as pastor of one of the city's four parish churches for two years until he was elected to succeed Oswald Myconius, who had died in the fall of 1552 , as pastor of the cathedral; in this position he was leader of Basel's church.

Sulzer's Lutheran tendencies did not endear him to his colleagues in the other evangelical cities of Switzerland. At the time of Sulzer's expulsion from Bern, his replacement, Johannes Haller, and the theology professor Eberhard von Rumlang complained to Heinrich Bullinger about the discord in the city's church, which they attributed directly to Sulzer. ${ }^{5}$ Although Bullinger

4. Hans Berner refers to the animosities which resulted from Sulzer's signature of the Consensus as background to Basel's refusal to sign the Second Helvetic Confession in 1566, but he does not describe the events of 1563 or discuss their immediate impact either inside or outside of Basel; see his "Basel und das Zweite Helvetische Bekenntnis," Zwingliana 15 (1979): 8-39. The main source of information on Sulzer is Gottfried Linder: Simon Sulzer und sein Anteil an der Reformation im Lande Baden sowie an den Unionsbestrebungen (Heidelberg, 1890) which is in need of revision. The most recent summary of Sulzer's life is the biographical sketch by Uwe Plath in Der Reformation verpflichtet. Gestalten und Gestalter in Stadt und Landschaft Basel aus fünf Jahrhunderten, ed. by the Kirchenrat der Evangelisch-reformierten Kirche Basel-Stadt (Basel, 1979), 43-48. 
corresponded regularly with Sulzer after the latter had been chosen as antistes, the Zurich reformer's suspicions about Sulzer's doctrinal reliability were kept alive by reports from other pastors in Basel, notably Johannes Jung and, after Jung's death in early 1562, Wolfgang Wissenburg. ${ }^{6}$ Both pastors were opponents of the "Lutheran" practices which Sulzer re-introduced in the Basel church, such as the use of the organ and of polyphonic music during worship services and the encouragement of private confession.?

The final break between Sulzer and Bullinger occurred at the beginning of November, 1562. Bullinger received an anonymous report that a Basel pastor had given a sermon in which he named as those who had rejected Christ "the papists, Jews, Turks and Schwärmer." In a terse letter to Sulzer, Bullinger pointed out that the Lutherans considered Oecolampadius and Zwingli to be Schwärmer and told Sulzer in no uncertain terms that he should warn the unnamed pastor not to link the Swiss with Turks and Jews. ${ }^{8}$ In his answer to Bullinger, Sulzer tried to gloss over the event. He began by reporting news from France, then discussed his own health problems, and then finally brought up the incident of the sermon. He pointed out that the rumors Bullinger had heard were distorted; he himself had been present at the sermon, and he had heard nothing which deserved criticism; no one had even dreamed of using the word Schwärmer, and in any case it was the policy of the Basel pastors to avoid doctrinal controversy. Then he changed the subject to discuss recent news from Germany. ${ }^{9}$ Sulzer's attempt to downplay

5. Eberhard von Rumlang to Bullinger: ZStA.E II. 346: 247 (July 13, 1548); E II. 360: 457 (Sept. 23, 1548); Haller to Bullinger: ZStA. E II. 370: 79 (Aug. 30, 1548).

6. In ZStA. E II. 336: 349-471 there are 113 letters from Sulzer to Bullinger, dating from Sulzer's election as pastor of the cathedral in 1553 to the end of 1560 . Although the archive has only two letters from the year 1561, there are eleven from the year 1562 (E II. 336: 472-482). Copies of most of these letters are also included in the Simlersche Sammlung of the Zurich Zentralbibliothek. Only a few letters from Bullinger to Sulzer survive. The ZStA has 18 letters from Jung to Bullinger written in 1561 (E II. 375: 631-645, 668-670), and 24 letters from Wissenburg to Bullinger written during 1562-63 (many of them in E II. 375: 677-686, 701-703).

7. For details, see Linder, Sulzer, 50-54.

8. ZStA. E II. 342 a: 463 b (Nov. 4, 1562).

9. ZStA.E II. 336: 481 (Nov. 14, 1562). Bullinger claimed that the sermon had been preached at the church of St. Peter, which led Linder (Sulzer, 55) to assume that it had been given by that church's pastor, Ulrich Coccius, who was Sulzer's brother-in-law and strongest supporter in Basel. In his response to Bullinger, however, Sulzer states that the sermon had been preached in the cathedral, not in the church of St. Peter. This not only undermines Linder's identification of Coccius as the offending preacher but also raises questions about the reliability of the anonymous report which Bullinger received. 
the incident was of no avail, however, and the ruptuse between the leaders of the two churches was made complete by the controversy which arose in Switzerland a few months later as a result of the Strasbourg Consensus. ${ }^{10}$

In February, 1562, the Basel city council had offered its pastors and university faculty as arbiters in resolving the dispute between the Strasbourg clergy and Academy. ${ }^{11}$ This proposal was actually carried out a year later, when the Strasbourg city council asked Pfalzgraf Wolfgang of Zweibriicken, Duke Christoph of Württemberg, and the Basel city council to send theologians who could settle the controversy. ${ }^{12}$ Basel sent Sulzer and, at Sulzer's request, his fellow pastor (and brother-in-law) Ulrich Coccius.

Once the theological and legal experts had arrived in Strasbourg, they spent several days reviewing the documents concerning the controversy which each side had written over the past two years. ${ }^{13}$ The mediators then met separately with each side, and finally they drew up several articles on the issues related to predestination. A general paragraph was later added to this document stating that the Lord's Supper would be taught in conformity with the Augsburg Confession, its Apology, and the Wittenberg Concord. This paragraph corresponded with a decision of the Strasbourg city council that the Augsburg Confession and its Apology, rather than the city's own Tetrapoli$\tan$ Confession, would serve as the doctrinal standard for the arbiters. ${ }^{14}$ The acceptance of the Augsburg Confession and Apology by the Strasbourg

10. For the time after the end of 1562 only two personal letters from Sulzer to Bullinger are extant (ZStA.E II. 336: 374, 483); Sulzer also signed the official letter of the Basel clergy to Bullinger explaining why they refused to sign the Second Helvetic Confession; ZStA. E II. 371: 1075 (Feb. 23, 1566).

11. The original of this offer in AST.55: 82; a draft of the offer in BStA. Missiven B 9: 11-13.

12. The Pfalzgraf sent Cunmann Flinsbach and the Duke sent Jakob Andreae. In addition, both princes thought it best to send two legal experts each to help with the negotiations. Zweibrlicken sent Wolf von Koeteritz and Heinrich Sweblin, Wurttemberg sent Daniel von Renchen and Kilian Bertz.

13. A description of the arbiters' work is given in the Bedencken they wrote for the Strasbourg city council after the controversy was settled: AST. 55: 170 r-173v; copy in BStA. Kirchen Akten A 9: 424r-430 r. For Sulzer's and Coccius' official account to the Basel city council, see BStA. Kirchen Akten A9: 416r-417r. Zanchi described his meetings with the arbiters in his letters to Calvin and Grindal; CR. Calv. Op.19: No.3936 (Apr. 18, 1563) and CR. Calv. Op. 20: No.3972 (undated). The articles signed at Strasbourg (hereafter referred to as the Consensus) are printed in CR. Calv. Op. 19: No. 3919.

14. For details, see Schmidt, "Zanchi," 661-662; Sohm, Schule, 234-235. 
magistrate as the city's official doctrine meant that there was little need to say more on the issue of the Lord's Supper in the Consensus.

While he did not write the articles of the Consensus, Sulzer played an important role in bringing about the formal reconciliation between Zanchi and Marbach. Despite his Lutheran leanings, he was probably more sympathetic to the Reformed position on the Lord's Supper than were Cunmann Flinsbach and Jakob Andreae, the Lutheran theologians from Zweibrücken and Wurttemberg. ${ }^{15}$ Andreae reported that Zanchi often consulted with Sulzer during his meetings with the arbiters. ${ }^{16}$ Perhaps Sulzer's most important contribution to the Consensus was his repeated reassurance to Zanchi that he and the other arbiters were in Strasbourg to draw up a formula which would end the controversy and reconcile the two sides, not to reach a final agreement on the doctrinal issues. At the official ceremony of reconciliation, Zanchi was unwilling to shake hands with Marbach, who still condemned Zanchi's teachings as heretical. At this point Sulzer took Zanchi aside and told him that the handshake did not mean that the two parties agreed on doctrine; such agreement could only be reached at a general synod. Instead, the handshake would signify two things: that Zanchi accepted the Consensus' formulation of doctrine, and that he sincerely forgave the other party for wrongs committed against him in the course of the controversy. Sulzer's reasoning was persuasive enough that Zanchi later used it to justify his actions. ${ }^{17}$

News of the events in Strasbourg spread quickly through Switzerland. Zanchi left Strasbourg a few days after the signing to spend some time at the baths of Baden in Aargau, then proceeded on to Engadin to visit his wife's family. On the way there he spent a few days in Zurich and told

15. Cf. Calvin's remark to Zanchi about the theologians called as arbiters: "Quum audirem Sulcerum et Iacobum Andream vocatos esse qui vestras controversias suo arbitrio componerent, de uno capite mediocrem spem concepi quod scirem de arcana Dei praedestinatione utrumque recte sentire, interea flexibile esse utriusque ingenium ad captandum favorem. In doctrina vero s. Coenae semper infelicem exitum mihi proposui. Sulcerus enim, ut morem gerat Lutheranis, medius videri appetit. Ab altero vero quid speres qui totus mancipatus est Brentio et se venditat." CR. Calv. Op.20: No. 3954 (May 13, 1563).

16. Jakob Andreae to Heinrich von Muilnheim and Carl Muieg, members of the Strasbourg city council: AST. 55: 173 v-174 r (Oct. 10, 1563). Andreae hastened to add, however, that this did not mean that Sulzer agreed with Zanchi's errors.

17. The ceremony is described by Zanchi to Calvin: CR. Calv. Op. 19: No. 3936; cf. ibid., No. 3920, Zanchi's report about the Consensus written to Mathias Erb soon after the official reconciliation. 
Bullinger of the events leading up to the signing of the Consensus. While in Zurich he also wrote a lengthy description of the events to Calvin. The Swiss theologians were less than happy with Zanchi's decision to sign the Consensus and counselled him to make a full profession of his true beliefs at the next opportunity. ${ }^{18}$

The first signs of displeasure in Zurich over Sulzer's role in the affair appeared two months after the signing of the Consensus. In two letters written in late May, Bullinger reported to Calvin that "Sulzer in Basel is slowly trying to lead that church from the true doctrine established there by Oecolampadius to the Lutherans. He has now joined himself to Marbach and his party, in open opposition to our churches, and subscribed to the Augsburg Confession and its Apology." ${ }^{19}$ He apparently sent the same news to Johannes Haller in Bern, warning him about an impending visit of Sulzer to that city and suggesting that the Strasbourg affair could be used in Basel to agitate against Sulzer. ${ }^{20} \mathrm{Haller}$, who was certainly no friend of Sulzer's, responded somewhat cautiously: "Concerning Basel, I don't know how we can get around them. He [Sulzer] certainly is a very slippery character and he gets away again and again. Moreover, he has many supporters, and the magistrates do not pay serious attention to such matters. But we ought to watch for any opportunity to include them, and we should pray that the Lord grant us the opportunity and free our churches from this plague."21 Haller invited Bullinger to visit Bern, so that they could discuss how to deal with Basel. When informed about Sulzer's activities and the possible measures to be taken against him, Theodore Beza responded more confidently: "What you wrote about the attempts of that flesh-eater is true, but I am confident that they will amount to nothing, since not only has this evil been foreseen but a remedy has been prepared. And I know that all the churches will agree

18. Calvin to Zanchi: CR. Calv. Op.20, No.3954 (May 13, 1563). Bullinger told Zanchi that he should seek complete freedom to teach from the Strasbourg city council, and if permission was denied, he should leave the city; see CR. Calv. Op.19, No. 3436.

19. CR. Calv. Op.20, No.3956 (May 21, 1563). Cf. his letter to Calvin of May 24, 1563; ibid., No. 3957.

20. Bullinger told Calvin that he had written to Bern (ibid., No.3957), but the letter has not survived.

21. Haller to Bullinger: ZStA.E II. 370: 310 (May 28, 1563): “Quod Basilienses attinet, weiß ich nitt, wie man hinder si möchte kon. Spiritus iste valde est lubricus et subinde elabitur. Accedit, quod fautores habent multos nec magistratus serio curant talia negotia. Vigilandum ergo, sicubi occasio se offerat, qua comprehendi possint et orandus est dominus, ut ille eam offerat ecclesiasque nostras hac peste liberet.” 
and steadfastly repudiate it totally."22 If Bullinger could devise a plan to eliminate Sulzer, both Haller and Beza were prepared to support it.

In his attack on Sulzer, Bullinger apparently hoped to make use of growing doctrinal discord in Basel. Wolfgang Wissenburg informed Bullinger in early June that many Basel citizens believed Zurich and the other Swiss churches "of the purer religion" rejected the Basel Confession of 1534. Wissenburg added that, in accordance with Bullinger's request, he was sending an account of the "Zanchi business," written in German. ${ }^{23}$ Wissenburg's account must have met with Bullinger's approval, for in describing the participation of the Basel pastors in the settling of the controversy, the author emphasized Sulzer's Lutheran leanings on the issue of the Lord's Supper. Wissenburg reported the events of the preceding March as Sulzer had related them to him, from the pastors' departure for Strasbourg to their return home, and he added that a copy of the Consensus had been made for the Basel city council. Wissenburg's description of Sulzer's account is straightforward and objective, but in the remainder of the letter his disapproval of Sulzer (and Coccius) is obvious: "How these [articles of the Consensus] have been received by the council, and whether they approve of them, I do not know. But it is true that I have heard of no one, either in the council or among the burghers, who does not want to remain by their Confession ${ }^{24}$ with steadfast will, even if they must expect suffering and trials for it. On the other hand, it is also true that both Herren Sulzer and Coccius brought Paul Eber's book on the Lord's Supper back with them from Strasbourg and praised the book highly to some people and asked them to read it with diligence; some of the ministers have read it but did not particularly like it. There is also another book by Martin Chemnitz that has been brought here, with the same arguments, that they have praised highly ... Since then, some have spoken from the pulpit about the corporal and essential presence and on the oral reception and oral distribution of the true body and blood of Christ through the hand of the minister more openly than before, which

22. Beza to Bullinger: Beza Cor.4: No. 271 (June 5, 1563).

23. Wissenburg to Bullinger: ZStA. E II. 375: 703 (June 6, 1563). Wissenburg had his own reasons to dislike Sulzer. The latter had replaced him first as pastor of the church of St. Peter in 1551 (allegedly because of the weakness of Wissenburg's voice), and then as professor of New Testament at the university in 1554; for details, see Johann W. Herzog: Athenae Rauricae sive Catalogus Professorum Academicae Basiliensis ab Anno MCCCCLX ad Annum MDCCLXXVIII (Basel, 1778-1780), 1: 27.

24. I.e., the Basel Confession, published as the city's official statement of faith in 1534. 
has much displeased many people who have rightly understood it." ${ }^{25}$ In Wissenburg's opinion, the growing sense of doctrinal difference between the Basel church and the other Swiss churches was Sulzer's fault. The antistes' contacts with the Lutherans in Strasbourg had encouraged him to a more vigorous promotion of Lutheran teachings in Basel. This was bound to arouse the opposition of the Zwinglians and so increase divisions and disunity both within Basel itself and between Basel and the other evangelical cities.

Wissenburg's letter provided further ammunition for Bullinger's campaign against Sulzer. Within a few days of receiving it, Bullinger wrote to Calvin that Paul Eber had written a book against the Swiss, and that Sulzer was highly recommending the work. ${ }^{26}$ Bullinger did not limit his attack to complaints about Sulzer to friends, however; he wanted some official action taken to stop Sulzer. This meant working through the city councils of Zurich and the other evangelical cities of German-speaking Switzerland, Bern, and Schaffhausen. At a meeting of the Swiss cantons held at Baden in July, 1563, delegates from Zurich, Bern, and Schaffhausen apparently discussed the Strasbourg affair and the situation in Basel. As a result of their discussion, they decided to draft a joint letter to the Basel city council expressing their displeasure with Sulzer's signature of the Consensus. ${ }^{27}$

25. ZStA.E II.345: 525: "Wie aber die selbige vonn einem ersammenn Rhatt anngenomen, ob sÿ die selbige Innen habenn lassenn gefallenn, ist mir nitt wüssennd. Wor ist aber, das Ich noch vonn niemanndts anderen weder der Rättenn noch der Burgerenn annderst gehörtt, dann das sÿ noch starker willenns seÿenn by Irer confessionn mitt der hilff Gottes zuo blibenn, ob glich ettwas kreÿts vnnd anfehtung dorob zuo erwarttenn were. Dargegenn aber ist auch wor, das bede herrenn Sulcerus vnnd Coccius Pauli Eberi buochlin vom nachmol mitt Innenn vonn Straßburg gebrocht vnndt ettlichenn lïttenn das selbig hochgelopt auch mitt fliß zuo lessenn Trüwlichenn gebettenn vnnd angesuocht, auch ettlich ex ministris die das selbig gelesenn aber nitt sonnders hochgefallenn dorann gehapt. Es ist auch sonnst noch ein annder biechlin Martini Kemnitz hargebracht wordenn ganntz eiusdem argumennti das auch bÿ Inenn hochgelopt vnnd geruompt würt ... Es habenn sÿch auch ettlich siderhar mer offennbar vonn der lieblichenn vnnd wesennlichenn gegennwürttigkeit auch vonn der Mündtlichenn empfachunng vnnd mündtlichenn darrÿchunng deß woren libs vnnd bluotts Christi durch die hannd des dieners vff der kanntzel vernemenn lassenn denn vormals. $\mathrm{Ab}$ welchen aber vil leütt wenig gefallenns gehapt die es Recht verstannden habenn." The books to which Wissenburg referred were Eber's Vom heiligen Sacrament des Leibes und Bluts unsers Herm Jesu Christi (Wittenberg, 1562) and Chemnitz' Repetitio sanae doctrinae de vera praesentia corporis et sanguinis Domini in coena (Leipzig, 1561).

26. CR. Calv. Op. 20: No.3968 (June 12, 1563).

27. Cf. Schaffhausen's response to Zurich: ZZB. Ms S 107: No.67 (July 24, 1563). 
Neither Bern nor Schaffhausen were prepared to go as far as Zurich in their official protest, however. The Schaffhausen city council endorsed the idea of an official protest signed by the three cities but did not think that the affair warranted sending an official legation to Basel. The response from Bern was even more cautious. The situation in that city was complicated by Sulzer's ties there, particularly because at the time that the Bern city council was deliberating its response to Zurich, Sulzer was in the city on personal business. ${ }^{28}$ Beat Ludwig von Mülinen, a member of the Bern city council, reported to Bullinger that the council had summoned Sulzer and asked him about his role in Strasbourg. Sulzer had told them about the negotiations, stating that the conflict chiefly concerned predestination and free will, and reported that everything was recorded in the documents which he had brought back to Basel. He also emphasized that he and Coccius had signed the Consensus only in their role as arbiters and not as an endorsement of its position on the Lord's Supper. ${ }^{29}$

Sulzer's presentation to the Bern city council influenced the official response sent by Bern to Zurich. It repeated Sulzer's statement that he and Coccius had signed the Consensus only as mediators and informed Zurich that Basel had a copy of the Consensus. The Bern city council suggested that the three cities should request a copy of the document from Basel so that they knew exactly what had been signed. ${ }^{30}$

Once the Zurich city council had received even this tentative approval from Bern and Schaffhausen, it wasted no time in drafting and sending an official letter to Basel. Reflecting the recommendations especially of Bern, the letter was not a protest so much as a request for more information: the three cities had recently learned of the settlement of the Strasbourg conflict, at which Sulzer and Coccius had been present; they were concerned by reports that the two Basel pastors had subscribed to the article on the Lord's Supper accepting the Augsburg Confession and Wittenberg Concord, but this was only hearsay, and they desired to know the truth. Therefore Zurich asked the Basel city council to send them a copy of the Consensus, including the article on the Lord's Supper, and promised to forward copies to the other two cities. ${ }^{31}$

28. On the possible reason for Sulzer's visit, see n. 55 .

29. ZStA.E II. 360: 557-559 (July 23, 1563).

30. Bern to Zurich: ZZB.Ms S 107: No.66 (July 23, 1563).

31. Zurich to Basel: BStA. Kirchen Akten A 3: 293-294 (July 26, 1563). 
Zurich's request to see a copy of the Strasbourg Consensus may have been politely phrased, but the underlying suspicion did not escape the Basel city council. As it happened, Bürgermeister Caspar Krug and Heinrich Falckner, a member of the city council, were representing Basel at a cantonal meeting in Baden when the Zurich letter arrived, and the responsibility for answering the letter fell on Krug's deputy. On July 28 an official response was sent to Zurich, stating that Sulzer and Coccius had been sent to Strasbourg at that city's request, to act with representatives from Zweibrücken and Württemberg to end the controversy there. An agreement had finally been reached after several days of negotiation; according to Sulzer's and Coccius' report, the controversy had concerned only the issue of predestination. As for the request for a copy of the Consensus, Sulzer and Coccius had described their activities in an oral presentation to the council upon their return, and Basel had no written documents concerning the controversy which it could send to Zurich. ${ }^{32}$

The Basel response seems reasonable enough, but it was a bald-faced lie. When Sulzer and Coccius returned from Strasbourg, they presented a written summary of their activities to the Basel city council. They also submitted a copy of the report of the arbiters to the Strasbourg city council, as Sulzer had told both Wissenburg and the Bern city council. Both documents mention the acceptance of the Augsburg Confession and Apology as the basis for all teaching on the Lord's Supper. ${ }^{33}$ It is also very probable that the Basel city council had received a copy of the Consensus, since the reports mention copies being made for the governments which had sent the arbiters. Acknowledging its awareness of the Consensus' statement on the Lord's Supper would have put the Basel city council in an awkward position, however. As antistes of the Basel church, Sulzer's actions had an official character. His signature of the Strasbourg Consensus, with its endorsement of the Augsburg Confession and its Apology could be (and was) interpreted as an acceptance by Basel of Lutheran teachings on the sacrament. This perceived movement by the Basel church towards the Lutheran position and away from the Zwinglian one would necessarily lead to tensions between Basel and its political and religious allies in Switzerland. To avoid such tensions, it was easier for the Basel city council to dissemble about its knowledge of the contents of the Consensus than to justify the actions of

32. BStA. Missiven B 9: 287-289.

33. These documents are in BStA. Kirchen Akten A9; they bear the notation "presentae et lectae Montag den 29. Martij, Ao 63" and are described in n.13. 
its antistes. By denying any knowledge of the Consensus' provisions regarding the Lord's Supper, the Basel city council hoped to avoid a confrontation with the other evangelical cities, and if their tactic was ultimately unsuccessful, it would at least maintain the appearance of unanimity among the cities for the time being and perhaps buy time for Basel to prepare a more detailed defense of its pastors.

This reasoning behind the city's deceptive response to Zurich is implied in a letter dispatched on July 29 to Krug and Falckner, the Basel delegates at Baden. Enclosing a copy of the Zurich letter and the city council's response, the Bürgermeister's deputy said he had not thought it would be wise to send a written copy of the Strasbourg Consensus. Once they had seen the letter from Zurich and Basel's response to it, the Basel delegates would know what to say to the delegates from the other three evangelical cities if they brought the matter up. The deputy also mentioned that Sulzer was returning from a visit to Bern, and if Krug and Falckner saw him, they should inform him of the city's official response to Zurich in case he was questioned about the affair. ${ }^{34}$

Unfortunately, the warning for Sulzer was too late, because he had already reported to the Bern city council that the documents were in Basel. It was clear that either Sulzer or the Basel city council was lying, and whether or not Zurich knew who the guilty party was, it was in their best interest to place all the blame on Sulzer. Not only did it avoid an uncomfortable confrontation with Basel, but it was one more way to blacken Sulzer's reputation. This was certainly the way Bullinger interpreted matters in a letter to Beza written on August 8. Sulzer, Bullinger reported, had told the Bern city council that the documents were deposited in Basel, but Basel said they had no written documentation; moreover they had been told that the conflict was only over predestination. In other words, Sulzer had lied to Bern and duped the Basel city council by not telling them the whole truth about the Strasbourg Consensus. ${ }^{35}$

Johannes Haller put the advantages of this position even more clearly in a letter to Bullinger: "I was sorry when [Sulzer] was called before the council, for it seemed that he satisfied many of them. But now I see that it was a good thing, because now he has been caught in a lie. I don't doubt that our

34. BStA. Missiven B 9: 289-291.

35. Beza Cor.4: No.281. Rudolf Gualther repeats the same sentiment in a letter to Beza, stating almost gleefully that "Sulzer was caught in a lie, which is not at all a new thing for him;" ibid., No. 290 (Sept. 29, 1563). 
side will take this very badly and will agree on a letter to send to Basel. If only he could be eliminated and the Basel church purged of this yeast!"36

This was also the official line taken by Zurich in informing the other two cities of Basel's response. Zurich reported to Bern and Schaffhausen that Basel had said that the Strasbourg conflict concerned only predestination, but a "trustworthy person" who had been present in Strasbourg had told Zurich what Sulzer and Coccius had signed concerning the Lord's Supper. Zurich enclosed a copy of this report (possibly from Zanchi himself) and suggested that since the Basel city council was unaware of the true contents of the Consensus, the three cities should send it a copy of the entire document along with the signatures. ${ }^{37}$

This time it was Schaffhausen which dragged its feet in agreeing to a new protest to Basel. Perhaps because they believed Sulzer had deliberately lied to them, Bern quickly agreed with Zurich's plan to send a copy of the Strasbourg Consensus to Basel, although they specified that Schaffhausen must also consent to the proposal. ${ }^{38}$ It took Schaffhausen longer to decide on a course of action. According to a letter from the Schaffhausen pastors to Bullinger, the Schaffhausen city council had asked for their opinion and had promised to be guided by their response. ${ }^{39}$ Two weeks later Jakob Rüger, one of the Schaffhausen pastors, wrote to Bullinger that the council's opinion would soon be sent to Zurich. ${ }^{40}$ Five days later the Schaffhausen city council suggested that the three evangelical cities write an "imposing letter" (ansehenliches Schreiben) to Basel. ${ }^{41}$

This "imposing letter" was sent to Basel on September 11. Because the Basel city council had received only an oral report of the Strasbourg Consensus from Sulzer and Coccius and had no written copy of it, Zurich had obtained a copy from a "trustworthy person" in Strasbourg, which it was now enclosing for Basel to see. The letter pointed out that the Consensus, signed by Sulzer and Coccius, not only concerned predestination but also

36. ZStA. E II. 370: 314 (Aug. 14, 1563): “Dolebam, quod ad senatum vocatus esset; visus enim fuerat plaerisque satisfecisse. Nunc verum video bonum hoc fuisse, cum ita deprehensus sit in mendacio, et non dubito, quin nostri hoc aegerrime sint laturi et consensuri in literas Basiliensibus mittendas. Utinam inde amoveri et ecclesia Basiliensis ab isto fermento expurgari possit!"

37. ZZB.Ms S 107: No.72 (undated).

38. ZZB. Ms S 107: No.73 (Aug. 19, 1563).

39. ZStA.E II. 375: 719 (Aug. 20, 1563).

40. ZStA.E II. 375: 720 (Sept. 3, 1563).

41. ZZB.Ms S 107: No.74 (Sept. 8, 1563). 
contained an article on the Lord's Supper which was completely opposed to the Basel Confession of 1534, which Basel had twice reaffirmed: the first time in 1548, and once more only recently when invited to send delegates to the Council of Trent. ${ }^{42}$ In view of the dangers caused by disunity and their obligation to defend their common Christian religion, the three cities formally requested that Basel denounce any actions taken by its pastors, whether in Strasbourg or anywhere else, which opposed the faith shared by all four cities. In addition, Basel should forbid its preachers and scholars to preach or teach anything which accorded with the Strasbourg Consensus, the Augsburg Confession or its Apology and so opposed the city's own confession, so that no division should arise between Basel and the other cities. Only the fear of arousing the attention of "those who oppose our religion" had deterred the cities from sending a special legation to Basel to demonstrate the depths of their concern about the situation. ${ }^{43}$

The second Zurich letter only fanned the flames of controversy which had been burning in Basel since the previous June. The Basel city council was already nervous, as indicated by the fact that it had confiscated a letter from Rudolf Gualther to the Basel pastor Severinus Erzberger written in early August because they thought it might contain a reference to the affair. ${ }^{44}$ Now they responded by procrastinating. In a letter dispatched to Zurich on September 13, the council acknowledged receipt of the Zurich letter and stated that, given the seriousness of the matter and the urgent press of business facing the council members, it could not respond immediately. The council asked that the three cities not be offended by the delay. ${ }^{45}$

42. This was a reference to Basel's two responses to the Catholic cantons concerning the Council. For the first response in 1548, and the city's disagreement with the other three evangelical cities concerning the Council of Trent, see Paul Burckhardt: "Basel zur Zeit des Schmalkaldischen Krieges," Basler Zeitschrift 38 (1939): 5-103, esp. 79-84; on the second response, see n.74.

43. BStA. Kirchen Akten A 9: $436 r-437 v ; 432 r-435 r$ is a copy of the Strasbourg Consensus in the same hand as the Zurich letter.

44. ZZB.Ms S 107: No.186 (Aug.3, 1563). Gualther was greatly offended by the Council's action and complained bitterly, not only in a letter to Erzberger (ZZB.Ms S 108: No. 48 [Sept.11, 1563]), but in a letter to Theodore Beza as well; Beza Cor.4, No. 290 (Sept. 29, 1563). Gualther's first letter to Erzberger is actually one long polemic against Sulzer. It begins with a reminder of the "purer doctrine of the Gospel" taught by Oecolampadius and Zwingli and affirmed in the Basel Confession of 1534, and then it attacks Sulzer's and Coccius' subscription of the Augsburg Confession and Apology, which condemned Swiss teaching on the sacrament.

45. BStA. Missiven B9: 309-10 (Sept. 13, 1563). 
Two letters to Bullinger written from Basel explain the reasons for the council's desire to delay its response. Wolfgang Wissenburg reported that when this latest letter from the three evangelical cities was read to the council, it had provoked a mixed reaction: some council members were surprised, others made excuses, and yet others refused to believe the charges. It was rumored that the response was being delayed until several council members had returned from the Frankfurt fair and elsewhere. Wissenburg also added in a postscript that Sulzer and Coccius reportedly would be called before the council to give account of their actions in Strasbourg. ${ }^{46}$ Johannes Hospinian stated more bluntly that the absent council members were "inclined to our adversaries," and he had little hope that the council's response would be favorable to the pro-Zurich party. ${ }^{47}$

Both men described dissension among Basel's citizens as well. According to Wissenburg, there were some who believed Zurich's position on the Lord's Supper "was the same as the Anabaptists', whom the Lutherans called Schwärmer, and the Sacramentarians', that is, those who, content with empty symbols, exclude Christ from the Supper." Others thought that the Basel Confession was closer to the Augsburg Confession than to Zurich's doctrines. Still others accepted neither the Zurich position, the Basel Confession, nor the Augsburg Confession. ${ }^{48}$ Hospinian reported that many Basel citizens believed that the Zurich pastors did not approve of the Basel Confession's statement on the Lord's Supper, and this had further alienated them from Zurich. He lamented the fact that there was no written statement on the sacrament by the Zurich clergy. Although he continued to assert that the Zurich and Basel positions were identical, he had no way to support his assertions, while "those who are in charge of the church" were actively inciting hostility towards Zurich. ${ }^{49}$

Hospinian's indirect request for a written statement of Zurich's doctrine did not fall on deaf ears. On September 29 Bullinger wrote directly to Bürgermeister Caspar Krug and the Basel city council..$^{50} \mathrm{He}$ had heard rumors, he reported, that many in Basel believed that he and his fellow pastors disapproved of the Basel Confession, particularly the article on the Lord's Supper, and he wanted to set the record straight. The churches of

46. ZStA. E II. 345: 533 (Sept. 14, 1563).

47. ZStA. E II.366: 284 (Sept. 20, 1563).

48. ZStA.E II.345: 533.

49. ZStA. E II. 366: 284.

50. BStA. Kirchen Akten A 9: $450 \mathrm{r}-\mathrm{v}$. 
Zurich, Bern, and the other evangelical Swiss cities recognized the doctrines of the Basel Confession as identical with their own teachings. What may have given rise to the rumors, Bullinger suggested, was the fact that the Zurich clergy did not believe that the Augsburg Confession and Apology affirmed the position held by the Swiss churches. To support this argument he enclosed a document which examined the differences between the positions more fully.

The document to which Bullinger referred was quite possibly a report on the Strasbourg subscription which exists in manuscript copy in Zurich. ${ }^{51}$ The report begins by stressing the unanimity of the four evangelical cities in their response to the seven Catholic cantons in 1548 and then summarizes the events in Strasbourg which led to the infamous subscription. The main section of the report, however, is comprised of statements emphasizing the true, substantial and essential presence of the body and blood of Christ in the sacrament. These statements are taken from the Augsburg Confession and Apology and from the writings of Luther and Lutheran theologians. The author dismisses those who had attempted to reconcile the Lutheran and Swiss positions, stating that any effort to interpret the Augsburg Confession to minimize the corporal presence of Christ was itself criticized by the Lutherans, who insisted "that the body of Christ is corporally present in the bread, eaten with the corporal mouth and distributed from the minister's hand, though in an indescribable way." ${ }^{52}$ The report asserts "that the Confession of the Swiss churches does not agree with the Augsburg Confession." This assertion is supported with Oecolampadius' statements at the

51. ZStA.E II. 371 a: 942 v-945 r: "Bericht wie die zwen predicanten zu Basel, herr Simon Sultzer vnd H. Ulrych Essich [Coccius], der Augspurgischen Confession vnd Apologia zu Straßburg vnderschriben habend, vnd was trännung der kylchen, wo man das nitt fürkumpt, darus volgen mag." I was unable to find a copy of this report or any similar document in the BStA; the letter from Bullinger to Krug preserved in the BStA does not include the document originally sent with it. It is possible that the report preserved in the ZStA was prepared and sent to Schaffhausen and Bern at the time Zurich was seeking their approval for the two letters sent to Basel. This latter possibility is supported by the harsh and direct criticism of Sulzer and Coccius in the report - which presumably would have been toned down if this document had been sent to Basel - and by the assertions that the article on the Lord's Supper in the Augsburg Confession is closer to Catholic teaching than to the Swiss position (a statement Gualther also makes in his letter of August 3 to Erzberger). It is conceivable that the document sent to Basel was a modified version of the main section of this report, dealing specifically with the Augsburg Confession's doctrine of the Lord's Supper.

52. Ibid., $945 \mathrm{r}$. 
Baden Disputation in 1526, the theses upheld at the Bern Disputation of 1528, and the Basel Confession of 1534. The document concludes that "the true, natural body of Christ sits at the right hand of God and not in the bread, but is present to the faithful, and his body and blood are consumed as a spiritual food through faith." 53

Within a few days of the letter's composition, Wissenburg could report to Bullinger on its reception in Basel. Wissenburg was lavish in his praise for the letter. He voiced his confidence that the letter and document would dispel any false assumptions which Krug may have had about the doctrine of the Zurich ministers. At the same time Wissenburg warned Bullinger not to mention Sulzer by name, because of the strength of the pro-Sulzer party in Basel. In fact, Wissenburg implicitly acknowledged Sulzer's authority in the city when he reported that Sulzer had just been created a doctor of theology, despite the opposition of some, including Wissenburg himself. ${ }^{54}$

It is striking that Sulzer was granted his doctorate at precisely this moment. Although Sulzer claimed that the city council had ordered him to obtain the title, Wissenburg was skeptical; as early as the previous June he had informed Bullinger that he and Martin Borrhaus had discovered provisions of the university statutes which could prevent Sulzer from achieving his goal..$^{55}$ Apparently Wissenburg and his allies were unsuccessful in this attempt to block Sulzer's promotion, and by early September they tried a new tactic. Wissenburg related to Bullinger their attempts to make clear Sulzer's deviation from the official doctrine of the Basel church, which according to the university statutes would be a valid reason for refusing to bestow the degree. Their ammunition was Sulzer's signature of the Augsburg Confession at Strasbourg, his fervent commendations of the book by Paul Eber, and his position as superintendent of the neighboring Lutheran church of upper

53. Ibid. The last section bears the subtitle, "Das die Confession der Eydtgnossischen Kylchen mitt der Augspurgischen nitt stimme."

54. ZStA. E II. 345: 534 (Oct. 4, 1563).

55. ZStA.E II. 375: 703 (June 6, 1563). Borrhaus was Sulzer's colleague on the theology faculty of the university. One of the statutes to which Wissenburg referred was possibly the requirement that all recipients of a doctorate in theology be of legitimate birth - Sulzer was the illegitimate son of the provost of a monastery in Interlaken in the Berner Oberland. It is likely that Sulzer's trip to Bern in July "on private business" was connected with this impediment, for at his promotion Sulzer presented sworn testimony from two Bern citizens (Ludwig and Bartholomaeus Archer) that Sulzer's father had "seen the light of the Gospel" and planned to marry the mother of his children but had died before he was able to carry out his intentions; see Herzog, Athenae Rauricae, 27-28. 
Baden. But Sulzer had been able to deflect each of these objections. Concerning his alleged acceptance of the Augsburg Confession and Apology, he had stated that the controversy at Strasbourg had arisen over the manner of speaking about the Lord's Supper, but there was no disagreement on the doctrine itself; ${ }^{56}$ moreover, the Consensus had endorsed the terminology of the Wittenberg Concord, which the Basel church had also accepted. Concerning Eber's book, he had especially praised its moderate tone; he had recommended it to others not in order to dictate their beliefs but so that they would have a chance to judge the work themselves. Finally, with regard to his responsibilities in Baden, Sulzer had stated that he had always tried to teach in such a way as would give offense to no one, and he was confident that he had done nothing which was opposed to the Basel Confession. ${ }^{57}$

Of course Sulzer's defense did not convince Wissenburg, but the opposition was obviously not strong enough to prevent Sulzer's promotion on September 28. Either Sulzer had the backing of a very powerful bloc in the church, university, and magistrate, or the pro-Zurich party was much weaker in Basel than seems apparent from their letters to Bullinger. Unfortunately, there are no extant documents which tell the story from the side of the pro-Sulzer party. Even Sulzer himself made no mention of his new title in a letter to Johann Marbach written a few days after the promotion. ${ }^{58}$ However, Theodore Beza alluded to the strength of Sulzer's supporters in a letter to Bullinger written on October 8 . He was glad that the three cities were taking action against Sulzer, but he stressed that they must not give up too easily or their efforts would be in vain. He then stated his worst fears: "before Sulzer dared take this step, he had either gathered defenders in his own city, or he believed that he had them outside the city, and I believe the latter is more likely than the former." The only remedy was for

56. ZStA.E II. 345: 531 (Sept. 8, 1563): "Quod de Coenae substantia nihil fuerit controversum inter partes, sed de loquendi tantummodo formula sit disseptatum in scholis et ecclesia uterentur utrique, nec qua dissentionis suspicio inter auditores suboriretur."

57. Ibid. Sulzer had held the position as superintendent of the Baden church since 1556, with the approval of the Basel city council; see Plath, "Sulzer," 47.

58. Johann Fecht: Historiae Ecclesiasticae Seculi A.N.C.XVI Supplementum; Plurimorum et Celeberrimorum ex illo aevo Theologorum Epistolis ad Joannem, Erasmum et Philippum Marbachios (Frankfurt, 1684), 157 (Oct. 4, 1563). There are few extant letters to or from Sulzer dating from the 1560s. In his letter to Marbach, Sulzer commiserates with the Strasbourg pastor over a renewal of the conflict with Zanchi but makes no mention of the dissent in Basel resulting from his own signing of the Consensus. 
the clergy to join together and exert pressure on their own governments, because "who can doubt that if we do not oppose this now, this fire will soon spread everywhere?" 59

Meanwhile, the Basel city council continued its efforts to eliminate dissent within the city. On October 4 they decreed that a new edition of the Basel Confession should be published. ${ }^{60}$ Wissenburg too worked actively to end the disagreements over the Lord's Supper - by vigorously promoting Zurich's doctrine (one suspects that Wissenburg's idea of peace did not coincide with that of the Basel city council). In mid-October he wrote to Bullinger that the chief hindrance to peace was still the belief, held by many, that the Zurich position differed from that of the Basel Confession because the Zurich clergy denied any presence of Christ in the sacrament. Wissenburg suggested that Bullinger write yet another letter, in German and in his own hand and addressed to him or any of the other Basel clergy, which would explain the true position of the Zurich church and could be used to silence the slanders against the Zurich church. Wissenburg admitted that Bullinger's earlier letter to the Bürgermeister and council had been without effect, but he felt sure that such a letter in the hands of a committed supporter of the Zurich position would accomplish more. ${ }^{61}$

Bullinger responded immediately to Wissenburg's request and wrote a letter to him in German explaining Zurich's doctrine of the Lord's Supper. ${ }^{62} \mathrm{He}$ explicitly rejected rumors that the Zurich clergy denied any presence of Christ in the sacrament and repeatedly stressed their acceptance of Oecolampadius' teaching, citing a specific passage from the latter's book written against Melanchthon. ${ }^{63}$ As a statement of the Zurich interpretation of the Supper he referred to the Consensus Tigurinus signed with Geneva. He also mentioned his recent letter to Bürgermeister Krug in which he had recognized the Basel Confession, including the article on the sacrament, as correct

59. Beza Corr 4, No.291. There was already a party which supported Sulzer in Bern; in a letter to Bullinger (CR. Calv. Op.20: No.4068 [Jan.9, 1564]), Jakob Rüger of Schaffhausen referred to a group in that city which was also inclined to accept the Augsburg Confession.

60. P.S. by Johann Erhart Battmann, another Basel pastor, in Wissenburg's letter to Bullinger; ZStA.E II. 345: 534 (Oct. 4, 1563).

61. ZStA.E II. 345: 535 (Oct. 18, 1563).

62. ZStA.E II. 345: 536-538. The letter is dated Oct. 21 and must have been written within a day or so after Bullinger received Wissenburg's letter of Oct. 18.

63. The work was Oecolampadius' Quid de eucharistia veteres tum Graeci, tum Latini senserint, dialogus (Basel: [Herwagen], 1530); Bullinger refers to explicatio 141. 
and conforming to the doctrines taught from the beginning of the Reformation of the Swiss churches. Bullinger authorized Wissenburg to show the letter either privately or publicly to whomever he wished in order to counter any mistrust, suspicion or discord resulting from an improper understanding of the Zurich church's position.

Wissenburg wrote back a week later. He thanked Bullinger for the letter, expressing his hope that it would help eliminate popular distrust of the Zurich clergy. He also brought Bullinger up to date on the latest developments in Basel. Sulzer and Coccius had been called before the city council to give their recommendations concerning the response to the letter from the three evangelical cities. The two pastors had repeated their acceptance of the Basel Confession's article on the Lord's Supper and had apparently satisfied the council (but not Wissenburg!). In the meantime, the council had ordered a new edition of the Confession and confirmed it, "as if by a new decree", and a copy had been distributed to every member of the council. Finally, on October 28, the council had ordered that all of the city's pastors and the entire faculty of the university preach and teach only those doctrines which were contained in the Basel Confession, and Wissenburg had heard that this decree would be extended to include all of the pastors in the surrounding countryside as well. ${ }^{64}$

Christian Wurstisen, a theology student in Basel, wrote on the same day to Johannes Wolf in Zurich that copies of the Basel Confession had been distributed to the pastors and theologians. While Jonas Grasser, another student at Basel, wrote to Bullinger that the new edition of the confession had been printed according to the older exemplar, Wurstisen stated that the new edition lacked the marginal glosses of the earlier editions. This modification was more significant than might otherwise appear, since the glosses had given a clearly Zwinglian slant to the article on the Lord's Supper. ${ }^{65}$

Having done its best to eliminate dissent and enforce uniformity among the clergy and theologians, the Basel city council now turned to the

64. ZStA.E II. 345: 539 (Oct. 29, 1563).

65. Wurstisen to Wolf: ZZB.Ms S 108: No.112 (Oct.29, 1563); Grasser to Bullinger: ZStA.E II. 375: 700 (Oct. 30, 1563). For discussion of the various editions of the Basel Confession and an analysis of the marginalia, see Karl R. Hagenbach: Kritische Geschichte der Entstehung und der Schicksale der ersten Baslerkonfession und der auf sie gegrïndeten Kirchenlehre (Basel, 1857), 31-36, 95-98. Hagenbach does not give a date for the edition of the Basel Confession without marginalia which he describes, although he does attribute it to the period when Sulzer was antistes. 
long-delayed task of drafting a response to the evangelical cities, a process which stretched to the end of the year. At last, on December 15, the council dispatched its answer to Zurich's letter of the previous September. Rather than responding directly, however, the council stated that its delegates to the cantonal meeting to be held in Baden in January would present Basel's answer to representatives of the three cities. ${ }^{66}$ The council clearly had no desire to put their answer to the three cities in writing. ${ }^{67}$ This could hardly have been the response that Zurich wanted, particularly since the Basel city council deflected attention from the Strasbourg affair even further by discussing it in connection with another conflict which had arisen between the boatmen of Basel and Zurich. Still, the Zurich city council had no alternative but to acknowledge receipt of the Basel letter and agree that its delegates, along with those of Bern and Schaffhausen, would be instructed to meet with the Basel delegates to hear their answer to the joint letter. ${ }^{68}$

At the same time, the Basel city council drafted the official response to be read by its delegates. In preparing the response, the council took as its starting point the justification of their actions offered by Sulzer and Coccius. According to Wissenburg's account, the two pastors had told the council to emphasize that they had gone to Strasbourg at the council's command in order to help end the controversy there, and that they had signed the Consensus not as an acceptance of the Augsburg or any other confession but simply in testimony of the achievement of concord. ${ }^{69}$ The two points of the pastors' justification, i.e., that they had acted at the command of the Basel city council and that they had signed the Consensus merely as witnesses, were incorporated into the first draft of the intended response to the three cities. ${ }^{70}$ The draft added further emphasis by stating that Sulzer and Coccius had been sent "at the request of our good friends and trusted dear neighbors from Strasbourg." It also asserted that the council had no

66. BStA. Kirchen Akten A 9: $445 \mathrm{r}-\mathrm{v}$.

67. This point is underlined by the Basel city council's instructions to its delegates to Baden, Bonaventura von Brunn and Hans Esslingen. The men were told first to read the letter from Zurich, then to read Basel's response point by point according to the accompanying document, and to stick by their oral response.If the delegates from the other cities asked for a written copy of the response, the Basel delegates were to refuse politely, saying that they had been instructed not to make copies. BStA. Kirchen Akten A 9: 447 r.

68. BStA. Kirchen Akten A9: 438 r (Dec. 24, 1563).

69. ZStA. E II. 345: 539 (Oct. 29, 1563).

70. BStA. Kirchen Akten A 9: $439 \mathrm{r}-440 \mathrm{r}$ (undated); the draft is in the form of a letter to Zurich. 
evidence that Sulzer and Coccius had done anything other than act as faithful arbiters, and this should not cause offense to the other Swiss cities. In a marginal note, the implied support of the pastors' actions was made even clearer: the Basel city council stated its approval of their pastors' actions and stressed its right, like any other magistrate, to send its pastors where it wished. As far as the complaint that Basel had forsaken its own confession, not to mention its common statements of faith with the other evangelical cities, the council expressed its "surprise and regret" that its actions had been interpreted in this way. There was no need to admonish Basel to adhere to its own confession, since the city's clergy preached nothing which did not conform to that confession. Moreover, there was no dissent about the confession either in the city itself or in its surrounding territories.

The final version of the official response followed the outline of this first draft but sharpened its message considerably. ${ }^{71}$ The final version strongly emphasized the city's support of "our dear and faithful ministers of the word of the Lord and rectors of our university," who had been authorized by the Basel city council to help settle the Strasbourg controversy. The council clearly endorsed the position that the signatures were meant only as witness to the Consensus, not acceptance of its contents, and in no way abrogated the city's own confession. Not only did the Basel city council have the right to authorize its clergy's actions, but it also had a duty, like all those zealous for God's honor, to do what it could to end strife and division. For this reason the other cities should not take offense at the actions of the Basel pastors. The final version made even more apparent Basel's "surprise, wonder, and hearty regret" that the other cities believed Basel had forsaken its earlier statements of faith. The council asserted that its preachers taught in conformity with the Basel Confession - although it now added the slight disclaimer, "according to our judgment, which the gracious God has given to us" - and it assured the three cities that there was no disagreement over

71. BStA. Kirchen Akten A 9: 441 r-444r; the cover page states, "Antwurt, unseren getrwen lieben Eydtgenossen den Statt Zurich vff ir schriben zugesandt, anno xv lxiii. Ist uss erkundtnus eines Ersamen Rates, mundtlich vff tag Baden vßgericht, vnnd den drey orten, Zurich, Berrn vnnd Schaffhusen, Rattsanmelten eroffnet, In Septembri 1563." The September date must refer to the original letter from the three cities. It is clear from Bullinger's correspondence that Basel had not responded to the letter until it informed Zurich in December that its delegates at Baden would present the city's answer at the upcoming meeting; cf. CR. Calv. Op.20, No. 4029 (Bullinger to Calvin: Sept. 28, 1563); see also Beza Cor. 4, Nos. 293, 296 (Bullinger to Beza: Oct. 10, Nov. 15, 1563). 
doctrine in Basel. The response closed by stating that there was no cause for friends to fear or enemies to rejoice that Basel had deviated from its confession.

This official response was clearly a victory for Sulzer and his supporters. Instead of censuring Sulzer and Coccius, as the letter of Zurich, Bern, and Schaffhausen had asked, the council had delivered a strong message of support for the actions of its clergy in Strasbourg, and for their preaching and teaching in Basel as well. In the face of such support there was little more that Bullinger and his supporters in Bern and Schaffhausen could do, and the matter was dropped. The protracted conflict both within Basel and between Basel and the other evangelical cities is significant, however, for it drew attention to Basel's growing theological and political independence and laid the foundation for its further alienation from the other evangelical Swiss churches.

The key issue within Basel itself was the interpretation of the article on the Lord's Supper in the city's official confession. The pro-Zurich party clearly believed that the article opposed the Augsburg Confession and that Sulzer had perjured himself by signing the Strasbourg Consensus and then accepting the Basel Confession. Sulzer's own position is not as clear. His first line of defense, that signature of the Consensus did not mean acceptance of the doctrines contained therein, was accepted by the Basel city council but by no one else. That Sulzer was capable of such mental reservation is illustrated by the arguments he used to persuade Zanchi to sign the Consensus. On the other hand, given Sulzer's support of a more Lutheran position on the sacrament in Bern, it is likely that he did accept the position of the Augsburg Confession, especially as interpreted by the Wittenberg Concord..$^{72}$ Moreover, according to Wissenburg, there were people in Basel who believed that the Basel Confession did not oppose the Augsburg

72. There is no reliable study evaluating the extent of Sulzer's "Lutheran" beliefs and examining any changes over time in his theology. He was branded as a Lutheran already during his years in Bern, and most later historians and theologians have simply accepted the judgment of Sulzer's contemporaries. In later years Sulzer did actively promote Lutheran views, both in Basel, where all clergy were required to sign the Wittenberg Concord in 1571, and in upper Baden, where the clergy were required to sign the Formula of Concord in 1578; for details, see Linder, Sulzer, 138-39, 103-111. There is some question, however, just how "Lutheran" Sulzer was in this earlier period. In any case, Sulzer's actual "Lutheran" beliefs in 1563 are not so important as the fact that he deviated from the Zwinglian doctrine of the Lord's Supper, which made him a Lutheran in the eyes of Bullinger and his supporters. 
Confession or who even thought that it accorded more closely with the Lutheran than with the Zwinglian doctrine on the sacrament. In any case, the Basel city council and Sulzer agreed that the article on the Lord's Supper in the Basel Confession should be left as ambiguous as possible. The elimination of the Zwinglian marginal glosses from the new, official edition of the confession only worked to Sulzer's advantage.

To make the situation more difficult for Bullinger and his supporters, Wissenburg's descriptions of the doctrinal dissent in Basel imply that many Basel citizens felt a certain loyalty to their city's official confession and were suspicious of what they regarded as Zurich's attempts to dictate to their church and clergy. In their appeals for support from Bullinger, Wissenburg and Hospinian requested not merely statements of the Zurich teaching on the Lord's Supper but also the reassurance that the Zurich clergy endorsed the position in the Basel Confession, since it was Zurich's perceived rejection of the Confession which caused so much offense. Tactically, it was wiser for Bullinger and for the pro-Zurich party in Basel to stress their approval of the Basel Confession and that Confession's agreement with Zurich doctrine than to utter any direct criticism of the Basel church or its leaders. Bullinger's references to Oecolampadius in his letters to Krug and Wissenburg could be understood as an appeal to this sense of loyalty.

A further complicating factor was the cordial hatred that most of the reformers outside of Basel felt for Sulzer. From the beginning both Bullinger and Haller hoped that the controversy would lead to Sulzer's ouster from his position in the Basel church. Even if he had wished to placate the other Swiss, Sulzer could have done nothing to improve his standing with them. Beza summed up the general attitude towards Sulzer in a letter to Bullinger: "I do not know whether it is worse that he subscribed to a doctrine which everyone knows he has always secretly harbored, or that he has persuaded others that he does not accept that teaching."73 Sulzer had already been tried and convicted as a Lutheran in the eyes of the other Swiss. It was Beza, however, who also pointed out that the controversy involved more than a personal vendetta against Sulzer. If Sulzer was allowed to go unopposed, he would only encourage others inclined to a more Lutheran position, not just in Basel but elsewhere in Switzerland as well. He was thus not merely offensive personally but a threat to the unity of the entire Swiss church.

73. Beza Cor.4, No. 285 (Sept.9, 1563). 
Because disunity in doctrine led to disunity in politics, the clergy of the Swiss cities were able to persuade their respective governments to take action against Basel. In their second letter the three cities inadvertently pointed to yet another reason for their concern: the recent response concerning the Council of Trent which Basel had given to the Catholic cantons independent of the other three cities. Basel had consistently tried to follow a conciliatory policy towards the Catholic cantons, and in early 1561 the Catholics had even hoped that Basel might send representatives to the final session of the Council. Basel clearly rejected the Council in 1562 but chose not to sign the joint response submitted by the other three cities. In a separate response the city preferred instead to reaffirm its initial response to the Council in 1548, which endorsed the 1534 Confession as its official statement of faith. ${ }^{74}$ As long as the Basel Confession was understood to be in accord with the positions of the other Swiss churches, this slight show of independence could be tolerated. If, however, Basel was moving towards a more Lutheran interpretation of the confession, the other cities were bound to view this as a genuine threat to the cities' united front. Again, the very ambiguity of the Basel Confession was the problem. In the eyes of the other Swiss cities, it was essential that Basel clarify the Zwinglian interpretation of its confession by disciplining Sulzer and Coccius and by forbidding the teaching of Lutheran doctrines, which they believed were opposed to the Basel Confession.

Both the clergy and the magistrates of the other Swiss cities misjudged the degree of support Sulzer had within Basel, however. Although the letters of the three Swiss cities created much consternation in the Basel city council, the city's magistrate in the end reacted against the pressure from outside by asserting its right to act independently and by endorsing the actions of its pastors. The city council made some attempt to placate Zurich by requiring all its pastors and professors to teach in accordance with the 1534 Confession, but it left the Confession open to interpretation by removing the Zwinglian glosses. Wissenburg had optimistically believed that the "purer doctrine" of the Zurich church would gain the upper hand, if only the right people could be convinced that Zurich did not reject the Basel Confession, but the ineffectiveness of Bullinger's letter to the Bürgermeister and council demonstrates otherwise. I have found no documents which might shed light on the

74. Karl Fry: Giovanni Antonio Volpe. Seine erste Nunziatur in der Schweiz (Fribourg, 1931), 125-132; on Basel's relations with the Catholic cantons see Berner, "das zweite Helvetische Bekenntnis," 25-26. 
theological convictions of the Basel councillors, but in view of their support for Sulzer it is clear that the majority did not want to be dictated to by Zurich either doctrinally or politically: Sulzer and the council proved to be allies, not adversaries.

The division between Basel and the other evangelical cities which emerged in 1563 had implications for the future. In early 1566 an attempt was made to have all the churches of Switzerland sign the Second Helvetic Confession as a common statement of faith. From the very beginning of the process of seeking approval, the Zurich clergy had doubts that Basel would accept the Helvetic Confession. Their pessimism proved well-founded, for the Basel clergy refused to sign the confession, stating that although they found no fault with it, they preferred to stand by their own Basel Confession of $1534 .^{75}$ At a time when the line between the confessions was becoming more sharply drawn, this commitment to an ambiguous formulation of doctrine and the attempt to find a middle ground between Reformed and Lutheran positions could only grow increasingly difficult to maintain. The controversy caused by the Strasbourg Consensus proved to be the opening round in a struggle between Sulzer and the Reformed clergy both within and outside Basel which ended only with Sulzer's death in 1585 and the election of Johann Jakob Grynäus, a confirmed supporter of Reformed orthodoxy, as his successor.

\author{
Amy Nelson Burnett \\ Department of History \\ University of Nebraska-Lincoln \\ Lincoln, NE 65588-0327
}

\title{
ZUSAMMENFASSUNG
}

Durch die Bemühungen Simon Sulzers, des Antistes der Basler Kirche, und anderer Vermittler wurde die bittere Auseinandersetzung zwischen Marbach und Zanchi mit der Unterzeichnung des Straßburger Konsensus (1563) durch die streitenden Parteien und die Vermittler beendet. In dieser Auseinandersetzung stand die Prädestinations-

75. On the atttempts to persuade Basel to sign the confession see Berner, "das Zweite Helvetische Bekenntnis." The fact that Rudolf Gualther was entrusted with the task of presenting the Confession to the Basel clergy was itself a sign that the Zurich clergy did not believe the Confession would be accepted. Gualther was Sulzer's most outspoken and bitter opponent in Zurich and certainly not the man to send on a mission which was meant to be conciliatory. 
lehre im Mittelpunkt. Im Konsensus wurde aber auch die Confessio Augustana und die Apologia als Norm für die Lehre vom Abendmahl anerkannt. Heinrich Bullinger und andere interpretierten daher Sulzers Unterzeichnung des Konsensus als (weiteren) Beweis für Sulzers Plan, die Kirche in Basel im Sinne des Luthertums umzugestalten. Um Sulzers Bemühungen zu blockieren (und ihn persönlich auszuschalten) und um die theologische und politische Einheit der reformatorischen Städte der deutschsprachigen Schweiz zu erhalten, versuchte Bullinger, in Zusammenarbeit mit der in Basel und in anderen Städten vorhandenen persönlichen und theologischen Opposition zu Sulzer und einer (gesellschaftlich anscheinend nicht einflußreichen) Zwingli-Partei in Basel, die Kirche in Basel zu einem offenen Bekenntnis zur Abendmahlslehre Zwinglis zu bewegen. Zugleich setzten Zürich, Schaffhausen und Bern den Rat von Basel unter Druck, Lehre und Predigt gemäß dem Straßburger Konsensus (oder gemäß der im Konsensus als rechtgläubig anerkannten Confessio Augustana und Apologia) zu verbieten. Das Ergebnis aller dieser Schachzüge war negativ: Basel stand zu Sulzer. Dieses Nachspiel des Straßburger Konsensus in der Schweiz bereitete den Weg Basels in die Isolierung: die Stadt weigerte sich, das Zweite Helvetische Bekenntnis zu unterzeichnen. 